\title{
The quality of lipid ingredients for pig diets: effects on performance, carcass and meat traits and adipocyte diameter
}

\author{
Qualidade dos ingredientes lipídicos para rações de suínos: efeitos \\ no desempenho, características de carcaça e carne e diâmetro dos \\ adipócitos
}

\author{
Daniel Pigatto Monteiro ${ }^{1}$; Aliny Kétilim Novais ${ }^{1}$; Louise Manha Peres ${ }^{1}$; \\ Nayara Andreo ${ }^{1}$; Luiz Gustavo Aristidis ${ }^{1}$; Adriana Lourenço Soares Russo ${ }^{2}$; \\ Julie Gabriela Nagi ${ }^{3}$; Alexandre Oba ${ }^{4}$; Ana Maria Bridi' ${ }^{4}$ Caio Abércio da Silva ${ }^{4 *}$
}

\begin{abstract}
This study aimed to evaluate the viability of using four lipid products (refined soybean oil, RO; degummed soybean oil, DO; pig lard, PL; and recycled frying oil, FO) as ingredients for pig feed during the finishing phase. The products were previously evaluated for the presence of insoluble impurities, peroxide levels, and total acidity as well as dioxin group, polychlorinated biphenyl, and polycyclic aromatic hydrocarbon contaminants. Eighty 110 day-old pigs, including 40 castrated males and 40 females, with a mean initial weight of $59.01 \pm 5.09 \mathrm{~kg}$, were subjected to four treatments (feed containing RO, DO, PL, and FO) for 32 days to evaluate the effect on growth performance, carcass and meat traits and adipocyte diameter. The results for the products did not reveal any degradation or presence of contaminants within the use restriction levels. There were no differences regarding performance, carcass and meat traits, and adipocyte diameter among the treatments. The animals fed FO feed exhibited a poorer loin area and marbling $(\mathrm{P}<0.07)$. The tested lipid raw materials are viable for use as ingredients in feed.
\end{abstract}

Key words: Chemical composition. Marbling. Recycled frying oil. Swine nutrition.

\section{Resumo}

Objetivou-se avaliar a viabilidade de uso de quatro produtos lipídicos (óleo refinado de soja, OR; óleo degomado de soja, OD; banha suína, BS; e óleo residual de fritura, OF) como ingredientes para rações de suínos em fase de terminação. Os produtos foram previamente avaliados quanto à presença de impurezas insolúveis, índice de peróxido, acidez total, contaminantes do grupo das dioxinas, bifenilpoliclorados e hidrocarbonetos aromáticos policíclicos. Foram utilizados 80 animais, 40 machos castrados e 40 fêmeas, com 110 dias de idade e peso médio inicial de 59,01 $\pm 5,09 \mathrm{~kg}$, durante 32 dias, submetidos a quatro tratamentos, representados por rações contendo OR, OD, BS e OF, sobre o desempenho zootécnico, características de carcaça e carne, diâmetro dos adipócitos e viabilidade econômica. Os produtos não apresentaram nenhum resultado de degradação ou presença de contaminantes dentro de níveis de restrição de uso. Não houve diferença para o desempenho, características de carcaça e carne e

\footnotetext{
1 Discentes do Curso de Doutorado do Programa de Pós-Graduação em Ciência Animal, Universidade Estadual de Londrina, UEL, Londrina, PR, Brasil. E-mail: daniel@tectron.ind.br; alinyketilim@hotmail.com; louise_mp@zootecnista.com.br; nayarandreo@hotmail.com; gustavinhoalessi@gmail.com

2 Prof ${ }^{a}$ Dra , Departamento de Ciência e Tecnologia de Alimentos, UEL, Londrina, PR, Brasil. E-mail: adri.soares@uel.br

3 Discente do Curso de Graduação em Zootecnia, UEL, Londrina, PR. Brasil. E-mail: gabrielanagi@hotmail.com

4 Profs. Drs., Departamento de Zootecnia, UEL, Londrina, PR. Brasil. E-mail: oba@uel.br; ambridi@uel.br; casilva@uel.br

* Author for correspondence
} 
diâmetro dos adipócitos entre os tratamentos. Animais tratados com rações com OF apresentarem pior área de lombo e marmoreio $(\mathrm{P}<0,07)$. As matérias primas lipídicas mostram-se viáveis para uso como ingredientes nas rações.

Palavras-chave: Composição química. Marmoreio. Nutrição de suínos. Óleo residual de fritura.

\section{Introduction}

Using lipid ingredients in the formulation of pig feed is common practice, with feed supplementation usually varying from 1 to 5\% (NRC, 2012). For animals with a high genetic potential, which show higher growth performance and; thus; exhibit greater nutritional demands; lipid sources must be supplemented to meet their demands, in addition to carbohydrates; proteins; and fiber (ROSTAGNO et al., 2011; NRC, 2012).

The lipid ingredients supplemented into the feed not only favor increased energy consumption by the animals but also improve feed intake and reduce pulverulence at feed factories and are associated with minimizing the release of volatile lipophilic compounds, which have significant olfactory inhibitory effects on consumption by swine (VIEIRA, 2010), thus improving their growth performance (PETTIGREW; MOSER, 1991; SMITH et al., 1999).

In Brazil, the following lipid sources are most commonly used to supplement pig feed (in decreasing order of participation): degummed soybean oil, poultry oil, pig lard, beef tallow, and as a co-product derived from the human food industry, recycled frying oil, which has shown an increasing supply due to the increased population and new consumer feeding habits (GIANNETTI; ALMEIDA, 2006; CENTENARO et al., 2008). Degummed soybean oil is effectively the most abundant; available, and stable of these sources (BEORLEGUI et al., 2010). In contrast; the use of pig lard; which is considered to have high nutritional value (BOURDON; HAUZY, 1993), is often limited due to the negative image associated with the nature of the lipid fraction, religious beliefs that hinder its consumption, and the operational difficulties of supplementing it into feed (due to being solid at room temperature). Additionally, in comparison with its frequent use as an ingredient for preparing processed meat products (BACKES et al., 2013), which have higher aggregate value, the use of pig lard as an ingredient in feed is more restricted (DEMEYER; DOREAU, 1999). Regarding recycled frying oil, there is little scientific information about its use to supplement pig feed. In the European Union, the use of recycled frying oil as an ingredient in animal feed is not allowed due to the risk of containing toxic compounds arising from its degradation/heating; such as polychlorinated biphenyls (PCBs) and dioxins (BLAS et al., 2010). Thus, this product is often considered a residue and is subjected to treatments to reduce environmental damage or is used as a raw material for biofuel production.

However, as the supplementation of feed with lipids is generally recognized to increase costs; recycled frying oil has strong appeal as an ingredient in providing animal nutrition (CZAPSKI, 2005). Its use as a supplement is also supported by a few studies that have revealed that recycled frying oil is irrelevant to organic damage in rats and swine consuming feed containing this ingredients (LUCI et al., 2007; BAUTISTA et al., 2014), provided that its origin and quality are preserved (WATANABE et al., 2001).

The concern about the use of lipid ingredients in livestock feed is also due to the possible consequences of the cumulative effect regarding human consumption of contaminated food (DUTHIE, 1993; GHIRETTI et al., 1997; VILUKSELA et al., 1998; QIAO; RIVIERI, 2001). Cereals; in addition to oils and fats, are among the most contaminated food sources (MAES et al., 2005). However, among more than $95 \%$ of cases of human exposure to contaminants, 60 to $80 \%$ were 
shown to be related to the ingestion of vegetables or meat, milk, or eggs (FURST et al., 1992; FFS, 2008).

In this context, this study aimed to determine the physical-chemical quality and presence of contaminants in the main lipid sources available in Brazil and to evaluate the effect of their use as ingredients in pig feed during the finishing phase on animal performance parameters, carcass traits, meat quality and adipocyte morphometry.

\section{Materials and Methods}

The project was approved by the Ethics Committee on Animal Use of the State University of Londrina (Universidade Estadual de Londrina), registered under number 17031.2013.86.

Eighty swine (Agroceres-PIC X Penarlan crossbreed), including 40 barrows and 40 females, with a mean initial age of 110 days and a mean initial weight of $59.01 \pm 5.09 \mathrm{~kg}$ were used. Two animals were housed per pen (one barrows and one female) for 32 days. The pigs were subjected to four experimental treatments consisting of feed containing different lipid sources, including refined soybean oil, degummed soybean oil, pig lard, and recycled frying oil, which were previously analyzed for petroleum ether-insoluble impurities, peroxide value, and total acidity (AOAC, 1996). Among the lipid sources, refined soybean oil and degummed soybean oil were obtained from an agribusiness cooperative in northern Paraná State, pig lard was obtained from an agribusiness cooperative in southwestern Paraná State, and recycled frying oil was obtained from a private company that collects this product within Paraná State Brazil.

The lipid sources were subjected to the analysis of 24 contaminants according to the methods and recommendations of the US Environmental Protection Agency (US EPA). The following seven contaminants belonging to the dioxin group were evaluated: 2,4,4' trichlorobiphenyl, 2,2',5,5' tetrachlorobiphenyl, 2,2',4,5,5' pentachlorobiphenyl, 2,3',4,4,5' pentachlorobiphenyl, $2,2^{\prime} 4,4^{\prime}, 5,5^{\prime}$ hexachlorobiphenyl, $2,2^{\prime} 3,4,4^{\prime}, 5$ hexachlorobiphenyl, and 2,2',3,4,4',5,5, heptachlorobiphenyl, according to EPA Method 1613, using high-resolution gas chromatography and high-resolution mass spectrometry (US EPA, 1997). For the polychlorinated biphenyls (PCBs), US EPA Method 8082A was employed to determine their levels in extracts from solid and liquid matrices via gas chromatography (US EPA, 1996). The following 16 contaminants belonging to the three polycyclic aromatic hydrocarbon (PAH) categories were evaluated to determine PAHs: naphthalene, acenaphthylene, acenaphthene, and fluorene, MMW-PAHs: phenanthrene, anthracene, fluoranthene, pyrene, benzanthracene, and chrysene, and HMW-PAHs: benzo(b)fluoranthene, benzo(k) fluoranthene, benzo(a)pyrene, indeno(1,2,3-cd) pyrene, dibenzo(a,n)anthracene, and benzo(g,h,i) perylene. US EPA Method 8270D was applied to determine PAH contents via gas chromatography and mass spectrometry analyses (US EPA, 2007).

The experiment for evaluating growth performance was conducted under a randomized block design. The blocks were based on the initial animal weight, with four treatments and ten replicates per treatment, where each stall was one replicate.

All the isocaloric and isonutrient experimental diets (Table 1) were calculated to meet the requirements proposed to support the demands of high-genetic-potential female pigs exhibiting higher performance during the finishing phase (ROSTAGNO et al., 2011). The energy values for the evaluated lipid sources were obtained from the composition tables reported by Rostagno et al. (2011), except for recycled frying oil, for which the energy value was obtained from the NRC (1998). 
Table 1. Percentage and calculated composition of the experimental pig feeds during the finishing phase.

\begin{tabular}{|c|c|c|c|c|}
\hline \multirow{2}{*}{ Ingredients $(\%)$} & \multicolumn{4}{|c|}{ Lipids sources } \\
\hline & $\mathrm{RD}^{1}$ & $\mathrm{DO}^{2}$ & $\mathrm{PL}^{3}$ & $\mathrm{FO}^{4}$ \\
\hline Corn & 62.38 & 63.12 & 62.82 & 62.76 \\
\hline Soybean meal & 31.05 & 30.91 & 30.96 & 30.98 \\
\hline Refined soybean oil & 3.70 & ----- & ----- & ----- \\
\hline Degummed soybean oil & ----- & 3.10 & ----- & ----- \\
\hline Pig lard & ----- & ----- & 3.35 & ----- \\
\hline Recycled frying oil & ----- & ----- & ----- & 3.39 \\
\hline Dicalcium phosphate & 1.08 & 1.08 & 1.08 & 1.08 \\
\hline Limestone & 0.59 & 0.59 & 0.59 & 0.59 \\
\hline L-Lysine & 0.14 & 0.14 & 0.14 & 0.14 \\
\hline Vitamin supplement $^{5}$ & 0.40 & 0.40 & 0.40 & 0.40 \\
\hline Salt & 0.40 & 0.40 & 0.40 & 0.40 \\
\hline DL-Methionine & 0.07 & 0.07 & 0.07 & 0.07 \\
\hline L-Threonine & 0.09 & 0.09 & 0.09 & 0.09 \\
\hline Mineral supplement ${ }^{6}$ & 0.10 & 0.10 & 0.10 & 0.10 \\
\hline Total & 100.00 & 100.00 & 100.00 & 100.00 \\
\hline \multicolumn{5}{|l|}{ Calculed values* } \\
\hline Metabolizable Energy (Mcal/kg) & 3.40 & 3.40 & 3.40 & 3.40 \\
\hline Calcium (\%) & 0.63 & 0.63 & 0.63 & 0.63 \\
\hline Phosphorus (\%) & 0.31 & 0.31 & 0.31 & 0.31 \\
\hline Lysina Digestible (\%) & 0.99 & 0.99 & 0.99 & 0.99 \\
\hline Met+ Cysteine Digestible (\%) & 0.58 & 0.58 & 0.58 & 0.58 \\
\hline Threonine Digestible (\%) & 0.64 & 0.64 & 0.64 & 0.64 \\
\hline Tryptophane Digestible (\%) & 0.19 & 0.19 & 0.19 & 0.19 \\
\hline Crude Protein (\%) & 19.20 & 19.20 & 19.20 & 19.20 \\
\hline
\end{tabular}

${ }^{1}$ Refined soybean oil; ${ }^{2}$ degummed soybean oil; ${ }^{3}$ pig lard; ${ }^{4}$ recycled frying oil; ${ }^{5}$ composition of the vitamin supplement per kg of product: $62 \mathrm{mg}$ folic acid; $1.625 \mathrm{mg}$ pantothenic acid; $2.500 \mathrm{mg}$ niacin; $100 \mathrm{mg}$ pyridoxine; $12.500 \mathrm{mg}$ feed efficiency improvement additive; $475 \mathrm{mg}$ riboflavin; $75 \mathrm{mg}$ selenium; $100 \mathrm{mg}$ thiamine; $750.000 \mathrm{IU}$ vitamin A; $1.750 \mathrm{mcg}$ vitamin B12; $150.000 \mathrm{IU}$ vitamin D3; $2.500 \mathrm{IU}$ vitamin E; $225 \mathrm{mg}$ vitamin $\mathrm{K} 3 ; 250 \mathrm{mg}$ antioxidant additive; ${ }^{6}$ mineral supplement composition per kg of product: $7.000 \mathrm{mg}$ copper; $40.000 \mathrm{mg}$ iron; $800 \mathrm{mg}$ iodine; $25.000 \mathrm{mg}$ manganese; $55.000 \mathrm{mg}$ zinc.

The animals received water and feed ad libitum throughout the experimental period, during which average daily gain, daily feed intake, and feed conversion were evaluated.

For the carcass and meat evaluations, a $4 \mathrm{x}$ 2 factorial design (4 lipid sources and 2 sexes) was adopted, where each animal constituted one replicate, with a total of ten replicates per treatment. The animals were stunned with an electrical current before slaughter using Petrovina ${ }^{\circledR}$ IS 2000 equipment containing two electrodes ( 350 Volts and 1.3 Amperes) for three seconds. After slaughter, scalding, toilette, and gutting, the carcasses were cut longitudinally and immediately weighed to obtain the hot carcass weight. The initial $\mathrm{pH}$ of the loin was measured at one hour after slaughter.

After cooling the carcasses at $2 \pm 1^{\circ} \mathrm{C}$ for 24 hours, they were individually evaluated to determine the hot carcass weight, cold carcass weight, carcass length, backfat thickness, Longissimus dorsi muscle depth, initial loin $\mathrm{pH}$, final loin $\mathrm{pH}$ (after 24 hours of cooling) through a potentiometer Testo, model 205; luminosity $\left(\mathrm{L}^{*}\right)$, color $\left(\mathrm{a}^{*}\right.$ and $\left.\mathrm{b}^{*}\right)$, water retention capacity, and marbling. The hot and cold carcass weights were used to determine the percentage of carcass weight loss during cooling, as cited by Bridi and Silva (2009). Backfat thickness and Longissimus thoracis (loin) muscle depth were 
measured from the height of the last rib to $6 \mathrm{~cm}$ from the cut's midline, according to AMSA (2001).

After 24 hours of cooling, a sample of the Longissimus thoracis muscle (approximately $15 \mathrm{~cm}$ ) was removed from each of the left halfcarcasses. The adjacent fat was removed from each loin, and five sub-samples (approximately $2.5-\mathrm{cm}$ thick) were then collected.

The samples were analyzed at 24 hours after slaughter using a Minolta CR10 portable colorimeter with an integrating sphere and an $8^{\circ}$ viewing angle (i.e., $\mathrm{d} / 8$ and $\mathrm{C}$ illumination to evaluate color). The $\mathrm{L}^{*}$ (luminosity), a* (red-green component), and $b^{*}$ (yellow-blue component) components were expressed using the CIELAB color system. The same samples were subjectively evaluated for marbling using photographic standards (NPPC, 1991), where scores of 1 to 5 were assigned ( $1=$ traces of marbling and $5=$ abundant marbling).

Water loss due to dripping was evaluated according to the technique described by Boccard et al. (1981), and water loss during thawing and cooking were evaluated according to the techniques described by Bridi and Silva (2009).

Samples from the analyses of water loss by thawing and cooking were used for the evaluation of meat tenderness, in which the samples were stored for 24 hours at $2 \pm 2^{\circ} \mathrm{C}$ after cooking. Shear force was measured using a Warner-Bratzler blade adapted to a Stable Mycro Systems TA-XT2i texturometer, oriented perpendicular to the direction of the muscle fibers (BOUTON et al., 1971). The speed was $5 \mathrm{~mm} / \mathrm{s}$ in pre and posttest and $2 \mathrm{~mm} / \mathrm{s}$ during the test.

To determine the adipocyte diameter, samples $( \pm 3 \mathrm{~cm})$ of intramuscular, intraperitoneal, and subcutaneous adipose tissue were collected and treated with a $10 \%$ formalin solution. Then, after dehydration and diaphonization in xylene, the samples were cut (3-to-5-micrometer-thick semiserial histological sections; five sections per sample) and stained with hematoxylin-eosin (HE). Evaluation was performed under 40X magnification, using an Olympus BX41 light microscope coupled to a system for capturing Olympus DP11-N images. The images were transferred to a computer and evaluated using Image-Pro Plus ${ }^{\circledR}$ software. Adipocytes were randomly selected, and a total of 30 cells per sample were evaluated.

The data were subjected to analysis of variance, and the means were compared via Tukey's test using the SAEG ${ }^{\circledR}$ statistical program, version 9.1 (UFV, 2007).

\section{Results and Discussion}

The values obtained through the physicalchemical analyses of the lipid ingredients (Table 2), where it can be seen that the values for parameters related to insoluble impurities were very low. There were important relative differences in peroxide values among the analyzed lipid sources. The total acidity values for all the lipid sources were considered low (Table 2).

The analytical results demonstrated that the values for the seven analyzed dioxins and the presence of polychlorinated biphenyls and PAHs were lower than the minimum detection limits for all the lipid sources.

For the performance parameters (Table 3) and carcass (Table 4) and meat quality (Table 5) traits, there was no difference between the treatments or interaction of the factors for any of the evaluated performance parameters. There was a trend $(\mathrm{P}<0.07)$ among the animals fed with recycled frying oilsupplemented feed of exhibiting a reduced loin area and marbling. Regarding the sex factor, the castrated males displayed a greater hot carcass weight and backfat thickness $(\mathrm{P}<0.05)$.

Regarding adipocyte diameter (Table 6), there was no difference among the treatments, although the values exhibited high variation. 
Table 2. Levels of insoluble impurities, peroxide levels, and total acidity of lipids sources used in pig feeds.

\begin{tabular}{lllll}
\hline Physical chemical parameters & $\mathrm{RD}^{1}$ & $\mathrm{DO}^{2}$ & $\mathrm{PL}^{3}$ & $\mathrm{FO}^{4}$ \\
\hline Insoluble impurities in petroleum ether $(\mathrm{g} / 100 \mathrm{~mL})$ & 0.02 & 0.02 & 0.02 & 0.04 \\
Peroxide rate $(\mathrm{mEq} / \mathrm{kg})$ & 5.99 & 9.37 & 2.90 & N.D. \\
Total acidity $(\mathrm{mg} \mathrm{KOH} / \mathrm{g})$ & $<0.1$ & 2.61 & 3.27 & 2.85 \\
\hline
\end{tabular}

${ }^{1}$ Refined soybean oil; ${ }^{2}$ degummed soybean oil; ${ }^{3}$ pig lard; ${ }^{4}$ recycled frying oil.

Table 3. Means of daily feed intake (DFI), final weight (FW), daily weight gain (DWG) e feed conversion (FA) of fattening pigs fed with rations formulated with different lipids sources.

\begin{tabular}{lcccc}
\hline \multirow{2}{*}{ Lipids sources } & \multicolumn{4}{c}{ Parameters } \\
\cline { 2 - 5 } & DFI $(\mathrm{kg})$ & FW $(\mathrm{kg})$ & DWG $(\mathrm{kg})$ & FA \\
\hline $\mathrm{RO}^{1}$ & 2.435 & 89.56 & 0.986 & 2.480 \\
$\mathrm{DO}^{2}$ & 2.448 & 90.07 & 1.000 & 2.440 \\
$\mathrm{PL}^{3}$ & 2.425 & 89.21 & 0.997 & 2.444 \\
$\mathrm{FO}^{4}$ & 2.533 & 92.01 & 1.046 & 2.427 \\
\hline Average & 2.460 & 90.21 & 1.007 & 2448 \\
\hline $\mathrm{P}$ value & 0.629 & 0.458 & 0.480 & 0.938 \\
\hline $\mathrm{CV}(\%)$ & 10.16 & 6.30 & 9.50 & 8.57 \\
\hline
\end{tabular}

${ }^{1}$ Refined soybean oil; ${ }^{2}$ degummed soybean oil; ${ }^{3}$ pig lard; ${ }^{4}$ recycled frying oil.

The results of the analyses of the physicalchemical properties of the lipid sources indicated their quality and safety as raw materials for feed formulation. The insoluble impurity levels of 2 to $4 \%$ observed in the oils and fats intended for animal feed are considered acceptable (NRA, 2003). Regarding the peroxide content determined for refined oil $(5.99 \mathrm{mEq} / \mathrm{kg})$, it remained above the recommended limit $(5.00 \mathrm{mEq} / \mathrm{kg})$ (BRASIL, 1999). However, that for degummed oil $(9.73 \mathrm{mEq} /$ $\mathrm{kg}$ ) indicated an advanced stage of oxidation, and an initial oxidation stage was indicated for the pig lard $(2.90 \mathrm{mEq} / \mathrm{kg})$. Nevertheless, all the values were below the recommended maximum limit of 10 $\mathrm{mEq} / \mathrm{kg}$ (BRASIL, 1999). In contrast, the peroxide was not detected in the recycled frying oil. For this product, it is noteworthy that the technique for the evaluation of peroxide content likely indicates low peroxide values during the final oxidation phase, considering the high instability of hydroperoxides when being converted into different secondary oxidation products, such as aldehydes and ketones, which is typical in the repeated heating of recycled frying oils (GRAY; CRACKEL, 1992). Nondetection of this compound in recycled frying oil does not predict the parameter's quality.

Concerning total acidity (Table 2), the values were within the quality standards established by Brasil (2005) and SINDIRAÇÕES (2013).

The detected dioxin levels were below $150 \mu \mathrm{g} /$ $\mathrm{kg}$, which validates the safety of the lipid sources in relation to these contaminants. There was a discrepancy between these values and those obtained by Schoppe and Kube-Schwickardi (1996), who identified 0.4 to $1.1 \mathrm{I}$-TEQ (ng/kg of fat) in pig lard samples. Likewise, the European Commission (EC, 2000) reported mean values of $1.0 \mathrm{WHO}-\mathrm{TEQ} / \mathrm{kg}$ of fat for pig lard and $0.2 \mathrm{ng}$ WHO-TEQ $/ \mathrm{kg}$ of dry matter for soybean oil. 
Table 4. Means of hot carcass weight (HCW), cold carcass weight (CCW), carcass length (CL), Longissimus dorsi muscle depth (LMD), backfat thickness (BT), loin area (LA) and marbling of pigs according the lipid source and gender evaluated.

\begin{tabular}{lccccccc}
\hline Lipid sources & HCW $(\mathrm{kg})$ & $\mathrm{CCW}(\mathrm{kg})$ & $\mathrm{CL}(\mathrm{cm})$ & $\mathrm{LMD}(\mathrm{mm})$ & $\mathrm{BT}(\mathrm{mm})$ & $\mathrm{LA}\left(\mathrm{cm}^{2}\right)$ & Marbling \% \\
\hline $\mathrm{RO}^{1}$ & 67.55 & 66.05 & 82.08 & $60.67 \mathrm{ab}$ & 9.08 & 41.51 & $1.75^{\mathrm{a}}$ \\
$\mathrm{DO}^{2}$ & 67.92 & 65.86 & 82.43 & $59.80 \mathrm{ab}$ & 8.45 & 41.99 & $1.58 \mathrm{ab}$ \\
$\mathrm{PL}^{3}$ & 68.38 & 66.44 & 83.53 & $62.00 \mathrm{a}$ & 8.65 & 41.42 & $1.68 \mathrm{ab}$ \\
$\mathrm{OF}^{4}$ & 67.19 & 65.32 & 83.48 & $55.80 \mathrm{~b}$ & 9.02 & 41.51 & $1.35 \mathrm{~b}$ \\
\hline Average & 67.76 & 65.92 & 82.88 & 59.57 & 8.80 & 41.61 & 1.59 \\
\hline Gender & & & & & & & \\
\hline Female & $66.62 \mathrm{~b}$ & 64.96 & 82.70 & 59.83 & $7.98 \mathrm{~b}$ & 41.09 & 1.50 \\
Barrow & $68.91 \mathrm{a}$ & 66.88 & 83.05 & 59.24 & $9.64 \mathrm{a}$ & 41.39 & 1.68 \\
\hline $\begin{array}{l}\text { P value } \\
\text { (treatment) }\end{array}$ & 0.943 & 0.950 & 0.605 & $0.069^{2}$ & 0.821 & $* * * *$ & $0.059^{1}$ \\
\hline P value (gender) & 0.056 & 0.105 & 0.813 & 0.696 & 0.003 & $* * * *$ & 0.146 \\
\hline CV (\%) & 9.93 & 10.18 & 9.08 & 12.90 & 32.01 & 12.22 & 34.28 \\
\hline
\end{tabular}

Different letters in the same column are significantly different by Tukey test

${ }^{1}$ Refined soybean oil; ${ }^{2}$ degummed soybean oil; ${ }^{3}$ pig lard; ${ }^{4}$ recycled frying oil.

Table 5. Means of water loss due thawing (WLT), water loss due cooking (WLC), shear force (SF), dripping loss $(\mathrm{DL})$, initial $\mathrm{pH}$, final $\mathrm{pH}$ and luminosity $\left(\mathrm{L}^{*}\right)$ and color $\left(\mathrm{a}^{*}\right.$ and $\mathrm{b}^{*}$ ) of pig meat according the differents lipid sources used like ration ingredients.

\begin{tabular}{|c|c|c|c|c|c|c|c|c|c|}
\hline Lipid sources & WLT (\%) & WLC (\%) & SF (kgf) & DL $(\%)$ & $\mathrm{pH}$ inicial & $\mathrm{pH}$ final & $\mathrm{L}^{*}$ & $a^{*}$ & $\mathrm{~b}^{*}$ \\
\hline $\mathrm{RO}^{1}$ & 6.81 & 21.81 & 4.00 & 1.31 & 6.43 & 5.60 & 55.45 & 5.83 & 11.20 \\
\hline $\mathrm{DO}^{2}$ & 6.55 & 21.09 & 3.71 & 1.33 & 6.48 & 5.61 & 55.27 & 5.58 & 10.88 \\
\hline $\mathrm{PL}^{3}$ & 7.68 & 22.78 & 3.67 & 1.32 & 6.43 & 5.61 & 56.19 & 5.82 & 11.11 \\
\hline $\mathrm{OF}^{4}$ & 6.53 & 21.37 & 4.18 & 1.30 & 6.50 & 5.59 & 56.44 & 6.09 & 11.54 \\
\hline Average & 6.89 & 21.76 & 3.89 & 1.31 & 6.46 & 5.60 & 58.84 & 5.83 & 11.18 \\
\hline \multicolumn{10}{|l|}{ Gender } \\
\hline Female & $6.26 \mathrm{a}$ & 21.52 & 3.92 & 1.32 & 6.42 & 5.60 & 55.42 & 5.98 & 11.12 \\
\hline Barrow & $7.53 b$ & 21.99 & 3.92 & 1.31 & 6.47 & 5.60 & 56.27 & 5.66 & 11.25 \\
\hline $\begin{array}{l}P \text { value } \\
\text { (treatment) }\end{array}$ & 0.2015 & $* * *$ & $* * *$ & 0.505 & 0.796 & 0.819 & 0.628 & 0.862 & 0.395 \\
\hline$P$ value(gender) & 0.018 & $* * *$ & $* * * *$ & 0.803 & 0.729 & 0.952 & 0.212 & 0.376 & 0.698 \\
\hline CV (\%) & 36.03 & 25.12 & 23.53 & 6.11 & 4.10 & 1.38 & 5.32 & 27.30 & 10.84 \\
\hline
\end{tabular}

Different letters in the same column are significantly different by Tukey test

${ }^{1}$ Refined soybean oil; ${ }^{2}$ degummed soybean oil; ${ }^{3}$ pig lard; ${ }^{4}$ recycled frying oil.

Table 6. Means of adipocyte diameter of intramuscular, intraperitoneal and subcutaneous fat of pigs in the finishing phase fed different lipid sources.

\begin{tabular}{lccc}
\hline Lipid sources & Intramuscular fat & Intraperitoneal fat & Subcutaneous fat \\
\hline $\mathrm{RO}^{1}$ & 154.62 & 147.08 & 143.93 \\
$\mathrm{DO}^{2}$ & 165.43 & 194.49 & 228.39 \\
$\mathrm{PL}^{3}$ & 123.14 & 223.84 & 219.84 \\
$\mathrm{OF}^{4}$ & 148.63 & 110.58 & 290.01 \\
\hline Average & 147.95 & 169.00 & 220.54 \\
\hline $\mathrm{CV}(\%)$ & 52.92 & 43.68 & 44.25 \\
\hline
\end{tabular}

${ }^{1}$ Refined soybean oil; ${ }^{2}$ degummed soybean oil; ${ }^{3}$ pig lard; ${ }^{4}$ recycled frying oil. 
Regarding the presence of polychlorinated biphenyls, all the lipid sources exhibited values lower than the minimum detection limit $(<150.0 \mu \mathrm{g} /$ $\mathrm{kg}$ ), corroborating the Feeding Fats Safety report (FFS, 2008), in which 0.04 to 1.10 pg of DL-PCB (WHO-TEQ/g of fat) was identified in 22 samples of pig lard, and 0.05 to 0.43 pg of DL-PCB (WHO$\mathrm{TEQ} / \mathrm{g}$ of oil) was identified in 8 samples of recycled frying oil.

The levels of PAH contaminants were lower than the minimum detection limit $(<1500.0 \mu \mathrm{g} / \mathrm{kg})$. This finding corroborates the Feeding Fats Safety report (FFS, 2008), in which among 36 pig lard samples, only three samples showed PAH contamination (above $2 \mathrm{ng} / \mathrm{g} \mathrm{BaP}$ ), and only two of eight samples of recycled frying oil contained above $2 \mathrm{ng} / \mathrm{g}$ BaP. These results show that the frying oils evaluated in the European Union, originating from several sources and origins, are not as depleted as previously thought and that the extent of contamination in frying oils is lower than expected.

The growth performance results indicated that none of the lipid sources interfered with feed palatability, and thus, their consumption had positive consequences for weight gain and feed conversion. Several previous studies involving the supplementation of different lipid sources (both plant- and animal-based products) into pig feed during the growth and finishing phases at different supplementation levels (between 3.87 and 10.97\%) also demonstrated that there was no difference in the evaluated performance indices (BEE et al., 2002; LUCI et al., 2007; DURAN-MONTGÉ et al., 2008; REALINI et al., 2010).

The similar animal performance observed was also due to the physical-chemical properties of these lipid sources (Table 2), which validates their use as ingredients for supplementation of animal feeds. Furthermore, according to Kellner et al. (2014), they do not have significant effects on digestibility that are distinct from the other dietary ingredients.
Regarding recycled frying oil, which is generally successively reused before it is intended for use in animal feed, degradation and the formation of toxic compounds, such as monomers, dimers, trimers, and other triglyceride polymers, are common, with these compounds accounting for up to $30 \%$ of this ingredient (PIRARD; PAUW, 2005), compromising intake and weight gain. However, this behavior was not effectively observed in the performance indices. Recycled frying oil is also highlighted as being more susceptible to lipid oxidation, given its high unsaturated fatty acid profile, which has negative effects on intestinal functions (BOU et al., 2005; NRC, 2012). Although oxidation of the frying oil examined in this study was not demonstrated, the evaluated parameters remained unchanged, which may be attributed to the resistance of these domestic animals to the feed's low lipid oxidation levels (NRC, 2012).

Regarding the effect on intake, Bautista et al. (2014) report that recycled frying oils can even favor this parameter compared with feeds containing raw oils because the latter oils generate more repulsive behavior in animals regarding intake.

Concerning the evaluated carcass traits (Table 4), the single effect of the sex factor on hot carcass weight and backfat thickness was due to the higher voluntary feed intake associated with this category (ZAMARATSKAIA et al., 2008).

The results obtained for the carcass parameters reflect the performance indices and show that the tested lipid sources may be used interchangeably. These findings are in accord with those of Bee et al. (2002) and Realini et al. (2010), who tested two lipid sources (cattle tallow and 5\% soybean oil supplementation) and five lipid sources (plantbased, animal-based, and blends, supplemented at from 4.5 to $11 \%$ ), respectively, and observed no advantages among the treatments.

There was a trend among the pigs fed recycled frying oil-supplemented feed $(\mathrm{P}<0.10)$ to exhibit a shallower muscle depth and lower marbling rate. 
These results contradict those obtained by Luci et al. (2007), who found that supplementing recycled frying oil, compared with frying oil used only once, promoted higher mRNA levels corresponding to two regulatory proteins of sterols (SREBP-1 and SREBP-2) and their target genes, leading to stimulation of liver production of triacylglycerol and cholesterol, thus highlighting their lipogenic effects.

The evaluated meat quality parameters indicate that the tested lipid raw materials did not exhibit a risk of compromising consumer demand. These results are similar to those observed by Mitchaothai et al. (2007), who supplemented pig feed with 5\% animal- and plant-based lipid sources during the growth and finishing phases.

The results of the meat percentage analysis corroborated the findings of Halas et al. (2010) and Duran-Montgé et al. (2008), who demonstrated the possibility of supplementing different lipid sources into pig feed without negative consequences for these parameters, but contradicted those of Kouba and Mourot (1998) and Realini et al. (2010), who indicated that ingredients with higher linoleic acid levels (plant-based oils compared with pig lard) increase muscle fat deposition.

Adipocyte diameter did not differ among the treatments (Table 6), which may be due to the isocaloric conditions of the diets and the levels of lipid ingredients supplemented into the rations, despite the high variation observed in the diameter measurements. However, the results contradict those observed by Kouba and Mourot (1998) and Realini et al. (2010), who indicated that diets with higher contents of linoleic acid increase body fat deposition, promoting a larger adipocyte diameter for pigs fed plant-based oil-supplemented feed, which contains more linoleic acid than pig lard.

\section{Conclusion}

The refined soybean oil, degummed soybean oil, pig lard and recycled frying oil evaluated did not exhibit degradation products and contaminants, can be used as lipid ingredients for finishing pig feeds with good results on growth performance, carcass traits, and meat quality.

\section{References}

AMERICAN MEAT SCIENCE ASSOCIATION AMSA. Meat evaluation handbook. Savoy: AMSA, 2001. p. 83-116.

ASSOCIATION OF OFFICIAL ANALYTICAL CHEMISTS - AOAC. Official methods of analysis of AOAC International. $16^{\text {th }}$ ed. Gaithersgurg: Association of Official Analytical Chemists, 1996. v. 2, 1995 p.

BACKES, A. M.; TERRA, N. N.; MILANI, L. I. G.; REZER, A. P. S.; LÜDTKE, F. L.; CAVALHEIRO, C. P.; FRIES, L. L. M. Características físico-químicas e aceitação sensorial de salame tipo Italiano com adição de óleo de canola. Semina: Ciências Agrárias, Londrina, v. 34, n. 6, p. 3709-3720, 2013.

BAUTISTA，R.; CARREON-TORRES, E.; LUNALUNA, M.; KOMERA-ARENAS, Y.; FRANCO, M.; FRAGOSO, J. M.; LOPEZ-OLMOS, V.; CRUZROBLES, D.; VARGAS-BARRON, J.; VARGASALARCON, G.; PEREZ-MENDEZ, O. Early endothelial nitrosylation and increased abdominal adiposity in Wistar rats after long-term consumption of food fried in canola oil. Nutrition, New York, v. 30, n. 9, p. 1055-1060, 2014.

BEE, G.; GEBERT, S.; MESSIKOMMER, R. Effect of dietary energy supply and fatty source on the fatty acid pattern of adipose and lean tissues and lipogenesis in pigs. Journal of Animal Science, Champaign, v. 80, n. 6, p. 1564-1574, 2002.

BEORLEGUI, C. B.; MATEOS, G. G.; REBOLLAR, P. G. (Ed.). Tablas FEDNA de composición y valor nutritivo de alimentos para la fabricación de piensos compuestos. $3^{\text {th }}$ ed. Madrid: FEDNA, 2010. 502 p.

BLAS, E.; CERVERA, C.; RODENAS, L.; MARTÍNEZ, E.; PASCUAL, J. J. The use of recycled oils from the food industry in growing rabbit feeds in substitution of fresh oil does not affect performance. Animal Feed Science and Technology, Amsterdam, v. 161, n. 1-2, p. 67-74, 2010. 
BOCCARD, R.; BUCHTER, L.; CASSELS, E.; CONSENTINO, E.; DRANSFIELD, E.; HOOD, D. E.; JOSEPH, R. L.; MACDOUGALL, D. B.; RODHES, D. N.; SHON, I.; TIMBERGEN, B. J.; TOURAILLE, C. Procedures for measuring meat quality characteristics in beef production experiments. Report of a working group in the commission of the European communities' (CEC) beef production research programme. Livestock Production Science, Amsterdam, v. 8, n. 5, p. 385-397, 1981.

BOU, R.; CODONY, R.; TRES, A.; BAUCELLS, M. D.; GUARDIOLA, F. Increase of geometrical and positional fatty acid isomers in dark meat from broilers fed heated oils. Poultry Science, Savoy, v. 84, n. 12, p. 1942-1954, 2005.

BOURDON, D.; HAUZY, F. Valeur nutritionnelle de sept matières grasses alimentaires pour le porc. Journées Rech Porcine en France, L'Hermitage, v. 25, n. 1, p. $157-$ 163, 1993.

BOUTON, P. E.; HARRIS, P. V.; SHORTHOSE, W. R. Effect of ultimate $\mathrm{pH}$ upon the water-holding capacity and tenderness of mutton. Journal of Food Science, Chicago, v. 36, n. 3, p. 435-439, 1971.

BRASIL. Agência Nacional de Vigilância Sanitária ANVISA. Resolução n. 482 de 23 de setembro de 1999. Aprova o regulamento técnico para fixação de identidade e qualidade de óleos e gorduras vegetais. Diário Oficial [da] República Federativa do Brasil, Brasília, 13 out. 1999. Seção 1, p.82-87.

\section{Agência Nacional de Vigilância}

Sanitária (ANVISA). Resolução n. 270 de 22 de setembro de 2005. Aprova o regulamento técnico para óleos vegetais, gorduras vegetais e creme vegetal. Diário Oficial [da] República Federativa do Brasil, Brasília, 23 set. 2005. Seção 1, p. 372.

BRIDI, A. M.; SILVA, C. A. Métodos de avaliação da carcaça e da carne suina. Londrina: Midiograf, 2009. $120 \mathrm{p}$.

CENTENARO, G. S.; FURLAN, V. J. M.; SOUZASOARES, L. A. Gordura de frango: alternativas tecnológicas e nutricionais. Semina: Ciências Agrárias, Londrina, v. 29, n. 3, p. 619-630, 2008.

CZAPSKI, S. No interior paulista óleo de fritura ganha status de biodiesel. Rio de Janeiro: ILUMINA, 2005. Available at: $<$ http://ilumina.org br/reciclagem-oleo-defritura-gera-energia-7eletrica/>. Accessed at: 3 set. 2013.

DEMEYER, D.; DOREAU, M. Target and procedures for altering ruminant meat and milk lipids. Proceedings of the Nutrition Society, Cambridge, v. 58, n. 3, p. 593607, 1999.
DURAN-MONTGÉ, P.; REALINI, C. E.; BARROETA, A. C.; LIZARDO, R.; ESTEVE-GARCIA, E. Tissue fatty acid composition of pigs fed different fat sources. Animal, Cambridge, v. 2, n. 12, p. 1753-1762, 2008.

DUTHIE, G. G. Lipid peroxidation EC. 2000. Opinion of the scientific committee on animal nutrition on the dioxin contamination of feedingstuffs and their contribution to the contamination of animal origin. Brussels. European Journal of Clinical Nutrition, London, v. 47, n. 11, p. 759-764, 1993.

EUROPEAN COMMISSION - EC. Opinion of the scientific committee on animal nutrition on the dioxin contamination of feedingstuffs and their contribution to the contamination of animal origin. Brussels: EC, 2000. $105 \mathrm{p}$.

FEEDING FATS SAFETY - FFS. Program of analytical control for the assessment of quality and safety of use of feeding fats in meat animal production. Feeding fats safety. Barcelona: UAB, 10 maio 2008. Available at: $<$ http://www.ub.edu/feedfat/Program\%20analytical $\% 20$ control.pdf $>$. Accessed at: 9 nov. 2013.

FURST, P.; BECK, H.; THELLEN, R. M. C. Assessment of human intake of PCDDs and PCDFs from different environmental sources. Toxic Substances Journal, Washington, v. 12, n. 1, p. 133-150, 1992.

GHIRETTI, S.; ZANARDI, E.; NOVELLI, E.; CAMPANINI, G.; DAZZI， G.; MADARENA， G.; CHIZZOLINI, R. Comparative evaluation of some antioxidants in salame milano and mortadella production. Meat Science, Oxford, v. 47, n. 1-2, p. 167-176, 1997.

GIANNETTI, B. F.; ALMEIDA, C. M. V. B. Ecologia industrial: conceitos, ferramentas e aplicações. São Paulo: Edgard Blucher, 2006. 109 p.

GRAY, J. I.; CRACKEL, R. L. Oxidative flavor changes in meats: their origin and prevention. In: LEDWARD, D. A.; JOHNSTON, D. E.; KNIGHT, M. K. (Ed.). The chemistry of muscle-based food. Cambridge: The Royal Society of Chemistry, 1992. p. 145-168.

HALAS， V.; BABINSZKY， L.; DIJKSTRA， J.; VERSTEGEN, M. W.; GERRITS, W. J. Efficiency of fat deposition from non-starch polysaccharides, starch and unsaturated fat in pigs. British Journal of Nutrition, Cambridge, v. 103, n. 1, p. 123-133, 2010.

KELLNER, T. A.; PRUSA, K. J.; PATIENCE, J. F. Impact of dietary fat source and concentration and daily fatty acid intake on the composition of carcass fat and iodine value sampled in three regions of the pork carcass. Journal of Animal Science, Champaign, v. 92, n. 12, p. 5485-5495, 2014. 
KOUBA, M.; MOUROT, J. Effect of high linoleic acid diet on delta 9-desaturase activity, lipogenesis and lipid composition of pig subcutaneous adipose tissue. Reproduction Nutrition Development, Paris, v. 38, n.1, p. 31-37, 1998.

LUCI, S.; KONIG, B.; GIEMSA, B.; HUBER, S.; HAUSE, G.; KLUGE, H.; STANGL, G. I.; EDER, K. Feeding of a deep-fried fat causes PPARa activation in the liver of pigs as a non-proliferating species. British Journal of Nutrition, Cambridge, v. 97, n.1, p. 872-882, 2007.

MAES, J.; MEULENAER, B. de; VAN HEERSWYNGHELS, P.; GREYT, W. de; EPPE, G.; PAUW, E. de; HUYGHEBAERT, A. Removal of dioxins and PCB from fish oil actived carbon and its influence on the nutritional quality of the oil. Journal of the American Oil Chemistrs Society, Champaign, v. 82, n. 8, p. 593597, 2005.

\begin{tabular}{llll} 
MITCHAOTHAI, & $\mathrm{J} . ;$ & \multicolumn{2}{c}{ YUANGKLANG, } \\
$\mathrm{C}$. & WITTAYAKUN, & $\mathrm{S} ;$ & VASUPEN, K.
\end{tabular}
WONGSUTTHAVAS, S.; SRENANUL, P.; HOVENIER, R.; EVERTS, H.; BEYNEN, A. C. Effect of dietary fat type on meat quality and fatty acid composition of various tissues in growing-finishing swine. Meat Science, Oxford, v. 76, n. 1, p. 95-101, 2007.

NATIONAL PORK PRODUCERS COUNCIL - NPPC. Procedures to evaluated market. $3^{\text {th }}$ ed. Iowa: Des Moines, 1991. 16 p.

NATIONAL RENDERERS ASSOCIATION - NRA. A buyer's guide to rendered products. Alexandria: NRA, 2003. 44 p.

NATIONAL RESEARCH COUNCIL - NRC. Nutrient requirements of swine. $10^{\text {th }}$ ed. Washington: National Press Academy, 1998. 189 p.

Nutrient requirements of swine. $11^{\text {th }}$ ed. Washington: National Press Academy, 2012. 400 p.

PETTIGREW, J. E.; MOSER, R. L. Fat in swine nutrition. In: MILLER, E. R.; ULLREY, D. E.; LEWIS, A. J. (Ed.). Swine nutrition. Toronto: Butterworth-Heinemann, 1991. p. 133-145.

PIRARD, C.; PAUW, E. Uptake of polychlorodibenzop-dioxins, polychlorodibenzofurans and coplanar polychlorobiphenyls in chickens. Environmet International, Amsterdan, v. 31, n. 4, p. 585-591, 2005.

QIAO, G. L.; RIVIERE, J. E. Enhanced systemic tissue distribution after dermal versus intravenous 3,3',4,4' tetrachlorobiphenyl exposure: limited utility of raio label blood area under the curve and excretion data in dermal absorption calculations and tissue exposure assessment. Toxicology and Applied Pharmacology, Amsterdam, v. 177, n. 1, p. 26-37, 2001.

REALINI, C. E.; DURAN-MONTGÉ, P.; LIZARDO, R.; GISPERT, M.; OLIVER, M. A.; ESTEVE-GARCIA, E. Effect of source of dietary fat on pig performance, carcass characteristics and carcass fat content, distribution and fatty acid composition. Meat Science, Oxford, v. 85, n. 4, p. 606-612, 2010.

ROSTAGNO, H. S.; ALBINO, L. F. T.; DONZELE, J. L.; GOMES, P. C.; OLIVEIRA, R. F.; LOPES, D. C.; FERREIRA, A. S.; BARRETO, S. L. T. Tabelas brasileiras para aves e suínos: composição de alimentos e exigências nutricionais. Viçosa, MG: Universidade Federal de Viçosa, 2011. 252 p.

SCHOPPE, G.; KUBE-SCHWICKARDI, C. In Untersuchungen zum Eintrag von PCDD und PCDF uber Tierkraftfutter in die menschliche Nahrungskette. Frankfurt: UBA-FB, 1996246 p. 246.

SINDICATO NACIONAL DA INDÚSTRIA DE ALIMENTAÇÃO ANIMAL - SINDIRAÇÕES. Compêndio brasileiro de alimentação animal. São Paulo: Sindirações, 2013. Available at: <www.sindiracoes. org.br/produtos-e-servicos/compendio-brasileiro-de10alimentacao-animal/>. Accessed at: 22 mar. 2014.

SMITH, J. W.; TOKACH, M. D.; O'QUINN, P. R.; NELSSEN, J. L.; GOODBAND, R. D. Effects of dietary energy density and lysine: calorie ratio on growth performance and carcass characteristics of growingfinishing pigs. Journal of Animal Science, Champaign, v. 77, n. 1, p. 3007-3015, 1999.

UNIVERSIDADE FEDERAL DE VIÇOSA - UFV. Sistema de análises estatísticas e genéticas - SAEG. Versão 9. 1. Viçosa, MG: Universidade Federal de Viçosa, 2007.

UNITED STATES ENVIRONMENTAL PROTECTION AGENCY - US EPA. Approval of EPA method 1613 for analysis of dioxins and furans in wastewater. Washington: United States Environmental Protection Agency, jul. 1997. Available at: <http://water.epa.gov/ scitech/methods/cwa/organics/dioxins/1613-fs.cfm $>$. Accessed at: 23 jul. 2014.

Method 8082: polychlorinated biphenyls (PCBs) by gas chromatography. Washington: United States Environmental Protection Agency, dec. 1996. Available at: <http://www.o2si.com/docs/epa-method-8082.pdf>. Accessed at: 23 jul. 2014. 
.Method 8270D: Semivolatile organic compounds by gas Chromatography/Mass spectrometry. Washington: United States Environmental Protection Agency, jan. 2007. Available at: <http://www.epa.gov/epawaste/ hazard/ testmethods/sw846/pdfs/8270d.pdf $\geq$. Accessed at: 21 jul. 2014.

VIEIRA, S. L. Consumo e preferência alimentar dos animais domésticos. Londrina: Phytobiotics Brasil, 2010.315 p.

VILUKSELA, M.; STAHL, B. U.; BIRNBAUM, L. S.; SCHRAMM, K. W.; KETTRUP, A.; ROZMAN, K. K. Subchronic/chronic toxicity of a mixture of four chlorinated dibenzo- $p$-dioxins in rats-I. Design, general observations, hematology, and liver concentrations. Toxicology and Applied Pharmacology, Amsterdam, v. 151, n. 1, p. 57-69, 1998.
WATANABE, C.; TANI, H.; FUJITA, K.; FUKE, T.; YOSHIDA, E.; NAKAIDO, T. Utilization of garbage dehydrated by the hot air drying method as feedstuffs for pigs. Animal Science Journal, Tokyo, v. 72, n. 10, p. 543550, 2001.

ZAMARATSKAIA, G.; RYDHMER, L.; ANDERSSON, H. K.; CHEN, G.; LOWAGIE, S.; ANDERSSON K.; LUNDSTRÖM, K. Long-term effect of vaccination against gonadotropin-releasing hormone, using Improvac $\mathrm{TM}$, on hormonal profile and behaviour of male pigs. Animal Reproduction Science, Dublin, v. 108, n. 1-2, p. $37-48,2008$. 